\title{
‘CENOCERAS ISLANDS' IN THE BLUE LIAS FORMATION (LOWER JURASSIC) OF WEST SOMERSET, UK: NAUTILID DOMINANCE AND INFLUENCE ON BENTHIC FAUNAS
}

\author{
DAVID H. EVANS ${ }^{1, *}$, ANDY H. KING² \\ 'Stratigrapher, Natural England, Rivers House, East Quay, Bridgwater, Somerset, TA6 4YS UK; e-mail: david.evans@naturalengland.org.uk. \\ 2 Director \& Principal Geologist, Geckoella Ltd, Suite 323, 7 Bridge Street, Taunton, Somerset, TA1 1TG UK; e-mail: andy@geckoella.co.uk. \\ * corresponding author
}

Evans, D. H., King, A. H. (2019): 'Cenoceras islands' in the Blue Lias Formation (Lower Jurassic) of West Somerset, UK: nautilid dominance and influence on benthic faunas. - Fossil Imprint, 75(1): 108-119, Praha. ISSN 2533-4050 (print), ISSN 2533-4069 (on-line).

\begin{abstract}
Substantial numbers of the nautilid Cenoceras occur in a stratigraphically limited horizon within the upper part of the Lower Jurassic (Sinemurian Stage) Blue Lias Formation at Watchet on the West Somerset Coast (United Kingdom). Individual nautilid conchs are associated with clusters of encrusting organisms (sclerobionts) forming 'islands' that may have been raised slightly above the surrounding substrate. Despite the relatively large numbers of nautilid conchs involved, detailed investigation of their preservation suggests that their accumulation reflects a reduction in sedimentation rates rather than an influx of empty conches or moribund animals. Throughout those horizons in which nautilids are present in relative abundance, the remains of ammonites are subordinate or rare. The reason for this unclear, and preferential dissolution of ammonite conchs during their burial does seem to provide a satisfactory solution to the problem.
\end{abstract}

Key words: Cenoceras, nautilids, benthic, sclerobionts, Watchet, Sinemurian

Received: April 10, 2019 | Accepted: June 25, 2019| Issued: August 29, 2019

\section{Introduction}

In West Somerset, UK, Lower Jurassic (Hettangian and early Sinemurian) strata are magnificently exposed in a series of low coastal cliffs and extensive intertidal reefs which adjoin the Bristol Channel. Here, alternating cycles of dark grey-black shales, paler mudstones and grey-yellow limestones are assigned to the Blue Lias Formation and lower Charmouth Mudstone Formation of the Lias Group; a total thickness of nearly $205 \mathrm{~m}$ is represented.

The sequence has been extensively studied for its geological structure, palaeontology and stratigraphy (Palmer 1972, Whittaker and Green 1983); coastal exposures at East Quantoxhead near Kilve contain the global stratotype section (GSSP Point) for the base of the Sinemurian Stage (Bloos and Page 2002) and a candidate international stratotype location for the base of the Hettangian Stage and Jurassic Period was considered at St. Audrie's Bay (Warrington et al. 1994). The West Somerset coast between Blue Anchor and Lilstock is recognised as being of national geological significance and receives statutory protection as a Site of Special Scientific Interest. Important new geological (especially palaeontological) discoveries are frequently made and the area retains considerable potential for further research especially regarding elements of sedimentology and palaeoecology that remain relatively unstudied.

Fossil ammonites predominate the cephalopod faunas through much of the Lower Jurassic succession along the West Somerset coast and in parts of the sequence are ubiquitous, whereas coleoid remains are extremely rare (Klug and Fuchs 2010). As elsewhere in the UK, the occurrence of very early Jurassic nautilids is relatively uncommon and only two species are currently known to occur on the West Somerset coast: Cenoceras malherbii (TERQuem) from the Hettangian Stage (Liasicus and Angulata zones) and C. intermedium (Sowerby) from the Sinemurian Stage (Bucklandi and Semicostatum zones).

This paper describes the recent discovery of two adjacent limestone beds at Helwell Bay, Doniford (just east of Watchet) in which nautilids dominate the cephalopod assemblage and ammonites are virtually absent. Although nautilids are present throughout these successions, their numbers are generally very small compared with ammonites. Horizons where nautilids form the dominant element are unusual and merit description since the presence of large numbers of nautilid shells on the sea floor appears to have had a marked influence on the nature of the associated benthic assemblages 


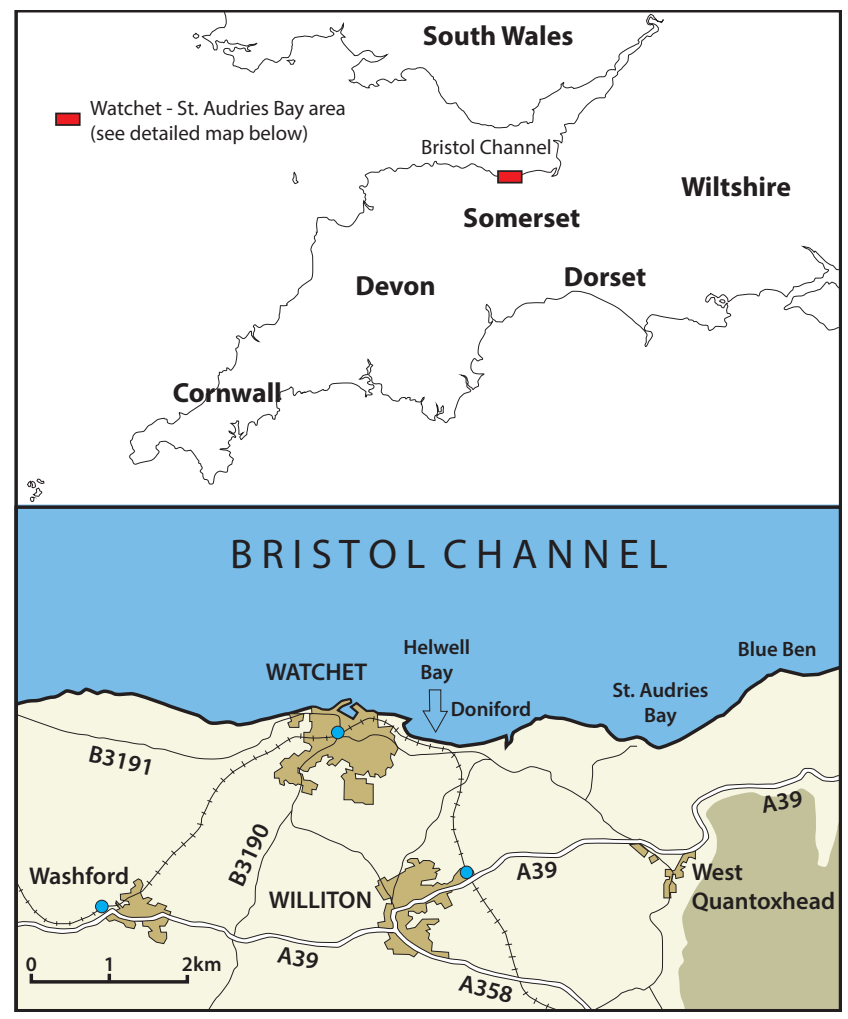

Text-fig. 1. Map of Southwest England indicating general and detailed location of the Watchet to St. Audries Bay area on the West Somerset coast.

and could reflect hitherto poorly understood aspects of nautilid palaeoecology. Where preservation permits features of the fossil nautilid shells to be distinguished (such as overall conch dimensions, whorl cross-section and external ornamentation), then the specimens can confidently be assigned to Cenoceras intermedium (SowerBy). However, many nautilid shells observed during this study are crushed, incomplete or fail to show diagnostic cross-sections, these are best considered as Cenoceras sp.

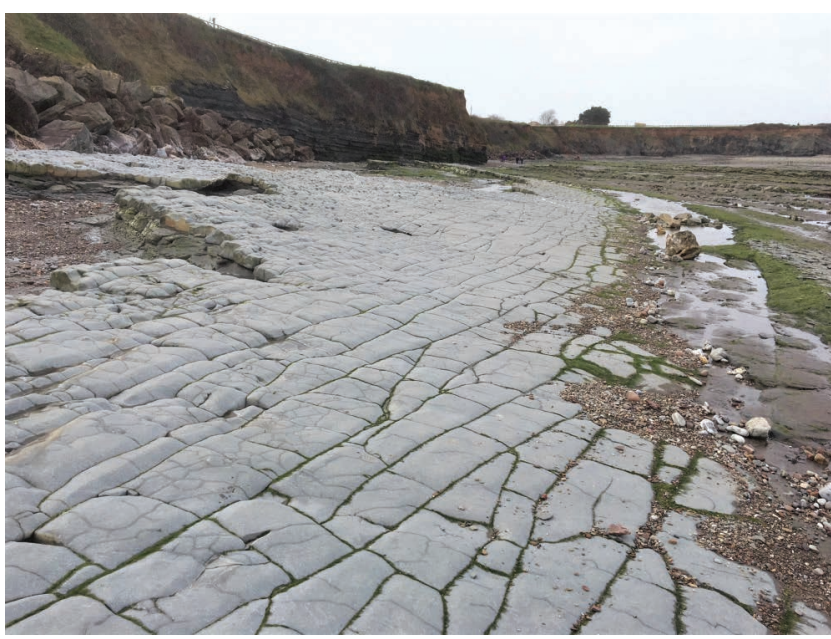

Text-fig. 2. General view of Helwell Bay, Doniford, looking west along the upper beach exposure and the Main Cenoceras Bed.

\section{Location and stratigraphical setting}

The small town of Watchet is located on the West Somerset coast $10.5 \mathrm{~km}$ south-east of Minehead and $30 \mathrm{~km}$ west-north-west of Bridgwater. This study was undertaken on Lower Jurassic strata exposed in Helwell Bay, situated 1 $\mathrm{km}$ east of Watchet, close to the village of Doniford (Text-fig. 1). In Helwell Bay, the low cliff sections and foreshore rock platforms immediately north of the West Somerset Railway line (adjacent to the rock revetment and groynes) expose a sequence of gently northward dipping early Sinemurian-aged shales and calcareous mudstones with occasional lenticular to persistent limestone bands. The latter tend to form east-west orientated platforms along the upper part of the beach (Textfig. 2); the extensive planar form of these platforms is highly characteristic of the West Somerset coast. The most prominent of these platforms is named the Main Cenoceras Bed in this paper; a thinner, impersistent and nodular limestone band containing fewer nautilids occurs $0.7 \mathrm{~m}$ higher in the sequence, this is named here as the Upper Cenoceras Bed.

\begin{tabular}{|c|c|c|c|c|c|c|}
\hline Group & Fmtn. & Palmer (1972) & Subzone & Zone & Stage & Series \\
\hline \multirow{12}{*}{ 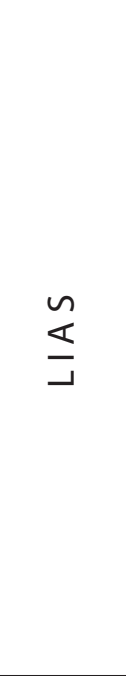 } & \multirow{2}{*}{$\sum_{U}^{u}$} & Helwell Marls & Resupinatum & \multirow{3}{*}{ Semicostatum } & \multirow{6}{*}{ 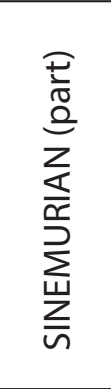 } & \multirow{12}{*}{ 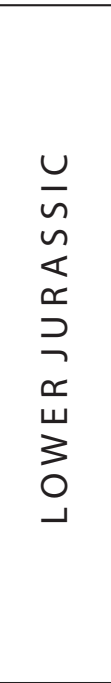 } \\
\hline & & Doniford Shales & Scipionianum & & & \\
\hline & & \multirow{2}{*}{ Quantocks Beds } & Lyra* & & & \\
\hline & \multirow{9}{*}{ 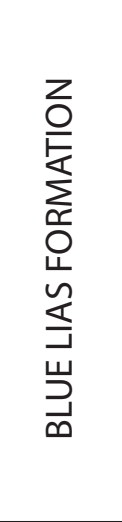 } & & Rotiforme & \multirow{3}{*}{ Bucklandi } & & \\
\hline & & \multirow{2}{*}{ Kilve Shales } & & & & \\
\hline & & & Conybeari & & & \\
\hline & & \multirow{2}{*}{$\begin{array}{l}\text { Blue Lias } \\
\text { (sensu stricto) }\end{array}$} & Complanata & & \multirow{6}{*}{ 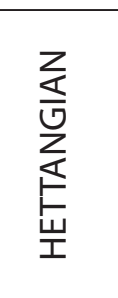 } & \\
\hline & & & Extranodosa & Angulata & & \\
\hline & & \multirow{2}{*}{ St. Audries Shales } & Laqueus & \multirow{2}{*}{ Liasicus } & & \\
\hline & & & Portlocki & & & \\
\hline & & \multirow{2}{*}{ Aldergrove Beds } & Johnstoni & \multirow{2}{*}{ Planorbis } & & \\
\hline & & & Planorbis & & & \\
\hline
\end{tabular}

Text-fig. 3. Lithostratigraphical and chronostratigraphical scheme for the Lower Jurassic of the West Somerset coast (CMF Charmouth Mudstone Formation; * the position of the Cenoceras Beds). 

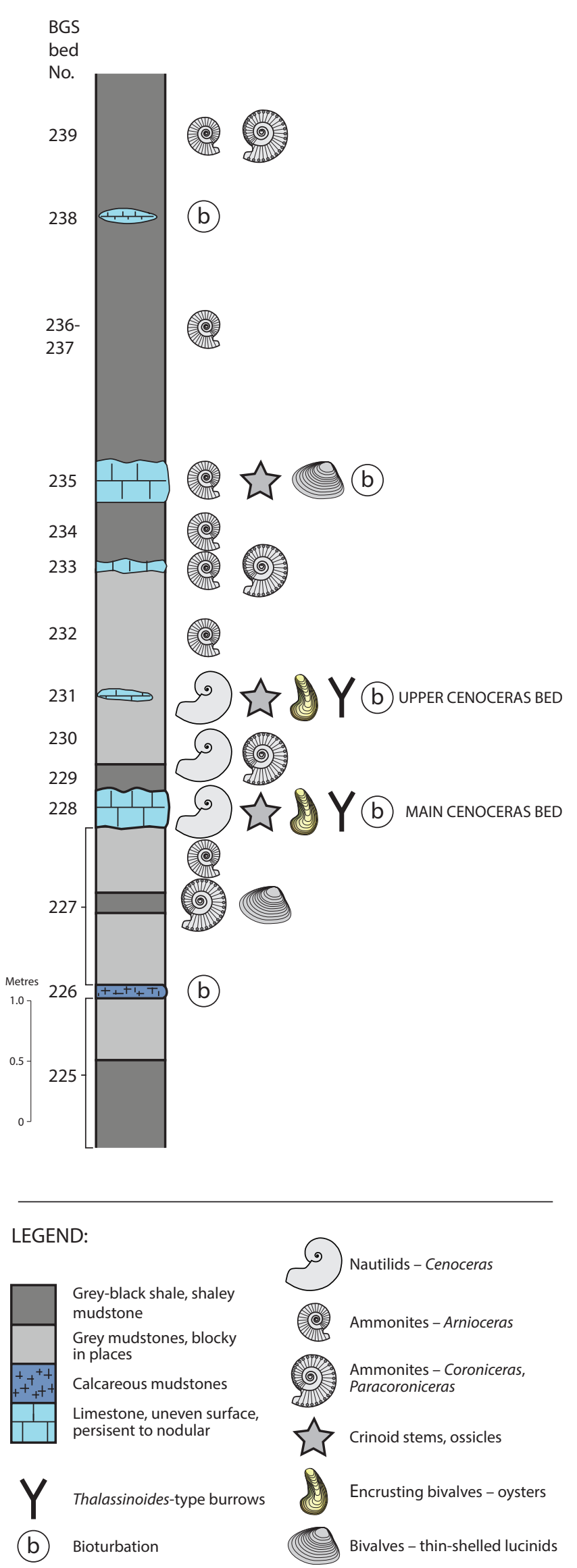

Text-fig. 4. Sedimentological log of the Main Cenoceras Bed and associated strata in the Quantocks Beds (Lyra Subzone) at Helwell Bay, Doniford (measured at NGR ST 08024314 and ST 0336 4305). BGS bed no. refers to bed numbers employed in Whittaker and Green (1983).
The lithostratigraphy and chronostratigraphy of the Lower Jurassic sequence of the West Somerset coast is shown in Text-figs 3 and 4. Both the Cenoceras beds and adjacent strata studied in Helwell Bay are assigned to the upper part of the Blue Lias Formation (upper part of the 'Quantock Beds' of Palmer 1972) and lie within the Lyra Subzone, Semicostatum Zone of the Sinemurian Stage.

\section{Material and methods}

The locations of each of the Cenoceras conchs or the site where a conch was once situated were recorded using Global Positioning System (GPS) and plotted on an aerial image (Text-fig. 5).

Other data (including the orientation of the conch relative to the bedding plane, degree of crushing of the conch, nature of sediments in the interior of the conch) were collected as field notes and also as images from which some of this data was extracted. As individual shells (either sclerobionts or those in the vicinity of the nautilid conchs) are only visible when exposed on the rock surface, no consistent and accurate counts of individual shells attached to or surrounding the nautilid conchs are possible. As a consequence, simple presence/absence data for such characteristics have been used throughout, and tabulated as numbers of nautilid conchs associated with a particular organism, in combination with the relative location of that organisim and the orientation of the nautilid conchs.

\section{Description}

\section{Occurrence and distribution}

Two limestone units (beds 228 and 231 of Whitaker and Green (1983)), one $0.7 \mathrm{~m}$ above the other are characterised by the frequent occurrence of Cenoceras across the bedding surfaces combined with a general paucity of ammonite remains. This study has focussed on the Main Cenoceras Bed, as the exposed area of bedding surface belonging to the Upper Cenoceras Bed is very small by comparison with the former. The contact of the lower unit with the intervening mudstones is sharp, and the freshly exposed bedding surface, apart from joint-sets is flat and featureless. This surface extends along the shore for approximately $450 \mathrm{~m}$ and has an estimated area of $900 \mathrm{~m}^{2}$. The removal of approximately 20 $\mathrm{mm}$ of material from the bedding surface by weathering and wave erosion reveals a much more heterogeneous surface exposing the remains of at least 65 individuals of Cenoceras in various states of preservation. Many of the conchs are associated with oyster and crinoid debris that is discretely distributed around them. Although the density of oyster and crinoid debris is negligible in the intervening areas between the nautilid conchs, there are 16 additional locations on the bedding plane where oyster and crinoid debris is concentrated. In each case the concentration is associated with a hollow in the bedding plane that marks the location of a nautilid conch removed by wave action. Together with the positive records of Cenoceras the density of nautilid remains on this bedding surface is $0.09 \mathrm{~m}^{-1}$ or one individual per $11 \mathrm{~m}^{2}$. 
Ammonites occur only in small numbers on the bedding surface and are subordinate to nautilids. Both nautilids and ammonites appear to be entirely lacking in the mudstones between the two nautilid-bearing units. But in the mudstone unit above the Upper Cenoceras Bed, the density of ammonites on bedding planes may range from 2-10 individuals per $\mathrm{m}^{2}$ (mean 5.25 per $\mathrm{m}^{2}$ ), while nautilids appear to be missing entirely.

The density of nautilid conchs on the bedding plane is greatest at the eastern and western extremities where the exposure is at its broadest ( 0.09 individuals per $\mathrm{m}^{2}$ ), but lower $\left(0.05 \mathrm{~m}^{2}\right)$ along the narrow middle stretch. Visual inspection of Text-fig. 5 suggests that there might be some clustering in the distribution of the conchs, but this might only be conclusively tested if a much larger area of the bedding surface was available for sampling. It is equally possible that the variation in the density distribution of the conchs is attributable to the variation in the width of the available exposure.

Limited vertical sections through the Upper Cenoceras Bed show individuals associated with crinoid debris that is dispersed laterally around and underneath the conchs (Textfig. 6a). The upper unit also contains at least one specimen of Cenoceras near the base of the unit, rather than toward the top, indicating that although the conchs may be concentrated near the tops of both units, they may also be sparsely distributed throughout both units.

\section{Orientation of conchs}

As there was no marker that could be used to consistently estimate the orientation of conchs in the horizontal plane, no attempt was made to record this. The resting positions of conchs range from vertical to horizontal; the majority of which are horizontal (Tab. 1).

\section{Integrity of conchs}

Of the 60 individuals where it was possible to determine the current resting inclination of the conch, in over half (61.7 \%) the body-chamber remains attached to the bodychamber, although it is not possible to estimate how many of the attached body-chambers are themselves complete. Over half (64.9\%) of these relatively intact conchs lie in horizontal positions, the rest being equally distributed between vertical and inclined. These proportions are broadly in line with the relative proportions of horizontally, inclined and vertically bedded conchs overall. Lone body-chambers represent $23.3 \%$ of the observed conch fragments, of which over half $(57 \%)$ rest in vertical positions. Isolated phragmocones represent an even smaller portion (5.0\%) of these individuals, and a further $11 \%$ consist of nautilid shell fragments, the origin of which cannot be determinated.

Of the contents of the phragmocones, over half (57.9\%) contain intact or partially intact septa, while the remainder are devoid of septa. This ratio holds for horizontally bedded individuals, but for inclined specimens the ratio rises to $75 \%$, and decreases to $43 \%$ for vertical conchs.

Conchs that have been compressed or crushed to a greater or lesser degree comprise $83 \%$ of all the individuals, the remaining $18 \%$ being uncrushed. All the horizontally bedded conchs are compressed or crushed to some degree, but this decreases to $82 \%$ and $46 \%$ respectively of the inclined and vertical individuals.

Where septa remain intact or partially intact (Text-fig. $6 \mathrm{~b})$ and are embedded in a matrix similar to the surrounding sediment and the conch has been compressed, the septa appear to be deformed, but show flexure rather than fracture. Where sediment is not present within the phragmocone, the septa are coated with sparite, and in cases where the conch has been compressed, the septa and sparite coatings are

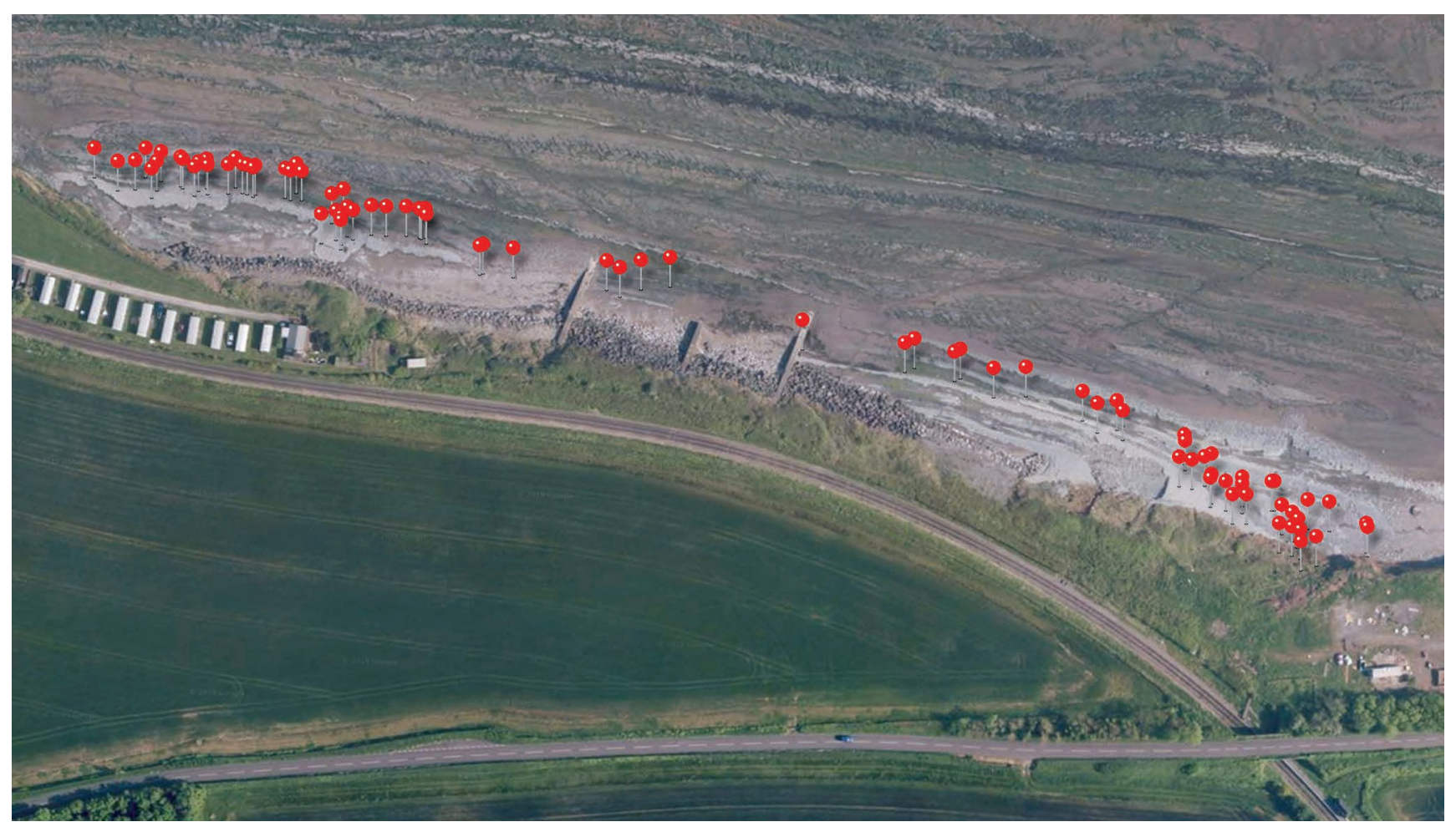

Text-fig. 5. Aerial view showing location of individual 'Cenoceras Islands' (marked by red pins) at Helwell Bay, Doniford. 

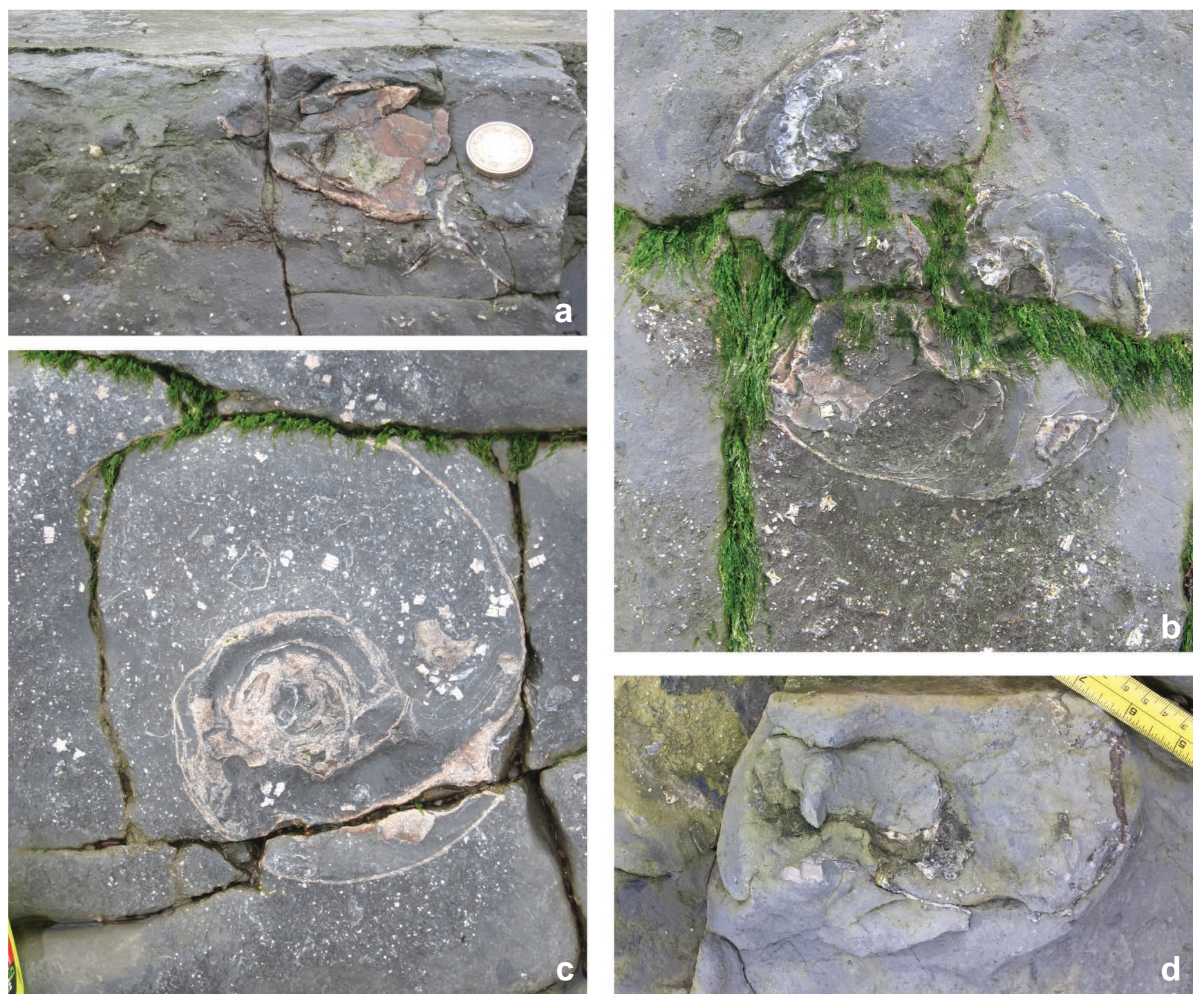

Text-fig. 6. a. Vertical section showing part of body-chamber of a Cenoceras in the top of the Main Cenoceras Bed associated with attached oysters below and stringers of crinoid debris below and stretching laterally. Coin $23 \mathrm{~mm}$ in diameter. b. Complete lateral half of conch showing intact and elastically deformed septa on which rests crinoid debris that spreads across the exposed septa and onto the adjacent substrate. Conch approximately $180 \mathrm{~mm}$ in diameter. c. Individual showing dispersed crinoid and molluscan debris within body-chamber and septa in the crushed inner whorls that have taken a sparite cement prior to, and after having undergone brittle deformation. $160 \mathrm{~mm}$ in diameter. $\mathrm{d}$. Vertically embedded specimen showing the loss of septa in the inner whorls that are infilled with matrix mottled by bioturbation. Tape measure provides scale.

generally broken and fractured (Text-fig. 6c), but may then be coated by a further generation of sparite.

\section{Sediment fills}

Except where only sparite is present, the sediment that fills the conchs appears similar to that of the surrounding matrix and may be confined to the outer whorls. Where the septa are largely or entirely missing from the conch, the conch may be almost entirely filled with sediment (Textfig. 6c, d) Crinoid debris comprises a relatively common component of the fill and in some individuals may form a thin layer both within the conch and over part of the area surrounding the conch (Text-fig. 6b).

\section{Bioturbation}

The Main Cenoceras Bed is bioturbated to the extent that individual burrows generally remain distinct and identifiable, but not so burrowed as to make the recognition of the burrowing trace taxa impossible. The assemblage includes Diplocraterion, Chondrites, Taendium, Rhizocorallium, Kulindrichnus and Thallasinoides. Diplocraterion and Chondrites are widely distributed across the bedding plane, while Taendium, Rhizocorallium and Kulindrichnus are more sporadic in distribution. Thallasinoides appears to be located only around Cenoceras conchs, where individual galleries are picked out by the concentrations of crinoid debris within them (Text-fig. 7c). Of those conchs containing sediment, in almost all (98 \%) the sediment is bioturbated. Some of the bioturbation cannot be attributed to a particular trace taxon, but is evidenced through the presence of mottled sediment (Text-fig. 6d). Distinct burrows attributable to Chondrites also occur (Text-fig. 6c, d). The presence of wisps and trails of crinoid and other shell debris within the conchs (Textfigs $6 c, 7 b$ ), together with of some evidence of the packing 

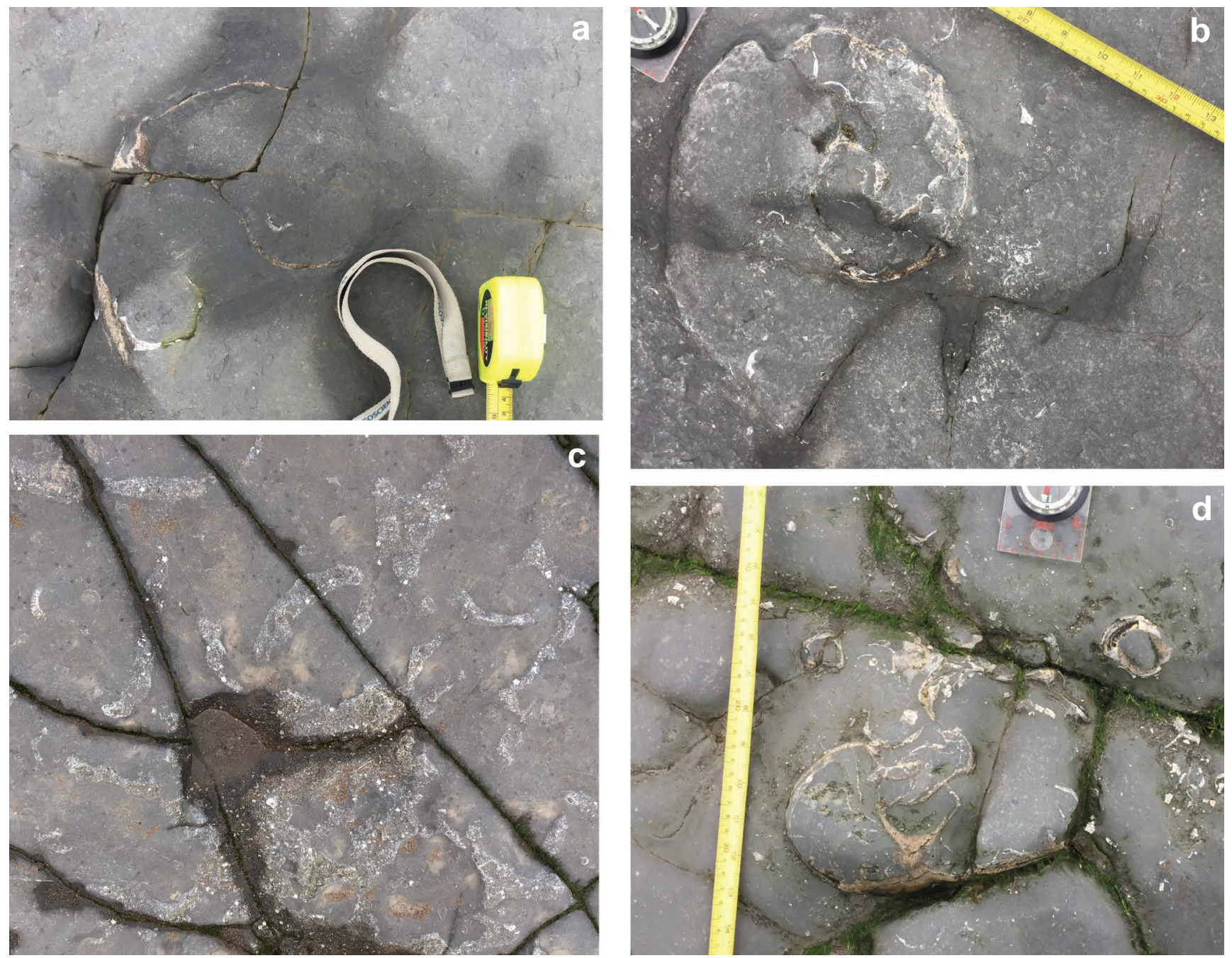

Text-fig. 7. a. Worn section through a horizontally bedded body-chamber and phragmocone, body-chamber showing oyster attached to inside of aperture as well as burrow mottling. Tape measure provides scale. b. Body-chamber and crushed phragmocone with body-chamber and phragmocone entirely filled with bioturbated matrix containing stringers of crinoid and molluscan debris. Flank of phragmocone encrusted by oysters. Tape measure for scale. c. Complex of Thallassinoides and Diplocraterion burrows associated with conch that has been eroded out by wave action. A few 'Ghostly' fragments of ammonite are also present. Original scope of the image approximately $400 \mathrm{~mm}$. c. Verically embedded conch with largely intact septa and camera infilled with burrowed matrix containing crinoid debris. Tape measure for scale.

of shell debris (Text-figs 6c, 7b) are further evidence of disturbance by burrowing organisms.

\section{Associated fauna}

Oysters (Liostrea), thin-shelled indeterminate bivalves and crinoid debris occur in association with many of the Cenoceras conchs (Tabs 2-4). Other bivalves including Gryphea, Oxytoma, Chlamys and Plagiostoma are infrequently and sporadically distributed through the Main and Upper Cenoceras beds. Although the presence of infaunal bivalves is suggested by the shapes of some of the burrow cross-sections, no body-fossils belonging to burrowing taxa have been seen.

Oysters are very much more abundant than thin-shelled bivalves, but both occur attached to the nautilid conchs and unattached, dispersed in the matrix. Where attached to the conch, they may be present on the venter, the lateral flanks, inside the body-chamber, or very rarely, within the phragmocone. Where they are dispersed in the matrix, oysters and thin-shelled bivalves may be distributed around the peripheries of the conchs (Text-fig. 8c), in the bodychamber (Text-fig. 7b) or at some distance from the conch (Text-fig. 8d).

Of the seventy-six locations where clusters of crinoid debris were found to be present, $54(71 \%)$ are associated with nautilid conchs. Of these, $26 \%$ include portions of articulated ossicles, about two-thirds of which are associated with horizontally embedded conchs. Approximately half the occurrences of completely disarticulated ossicles are associated with horizontally bedded conchs, with the remainder approximately equally distributed between inclined and vertical conchs.

None of the conchs show any evidence of the presence of crinoid holdfasts, although they could quite easily remain obscured by the matrix. While there is a clear association between the conchs and crinoid debris, there are cases (Textfig. 6b) that show cross-cutting relationships between the conch and the crinoid debris such that ossicles are resting on the surfaces of consecutive septa within the phragmocone 

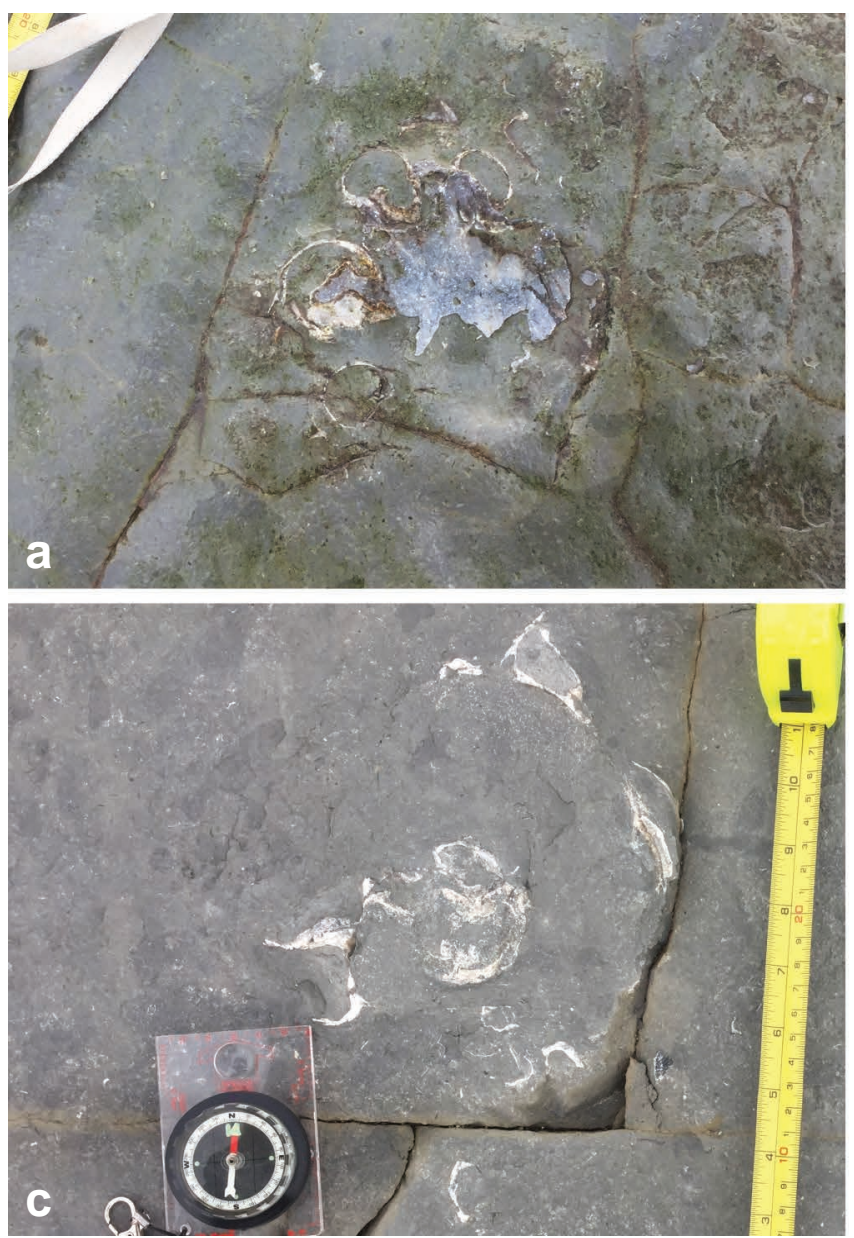
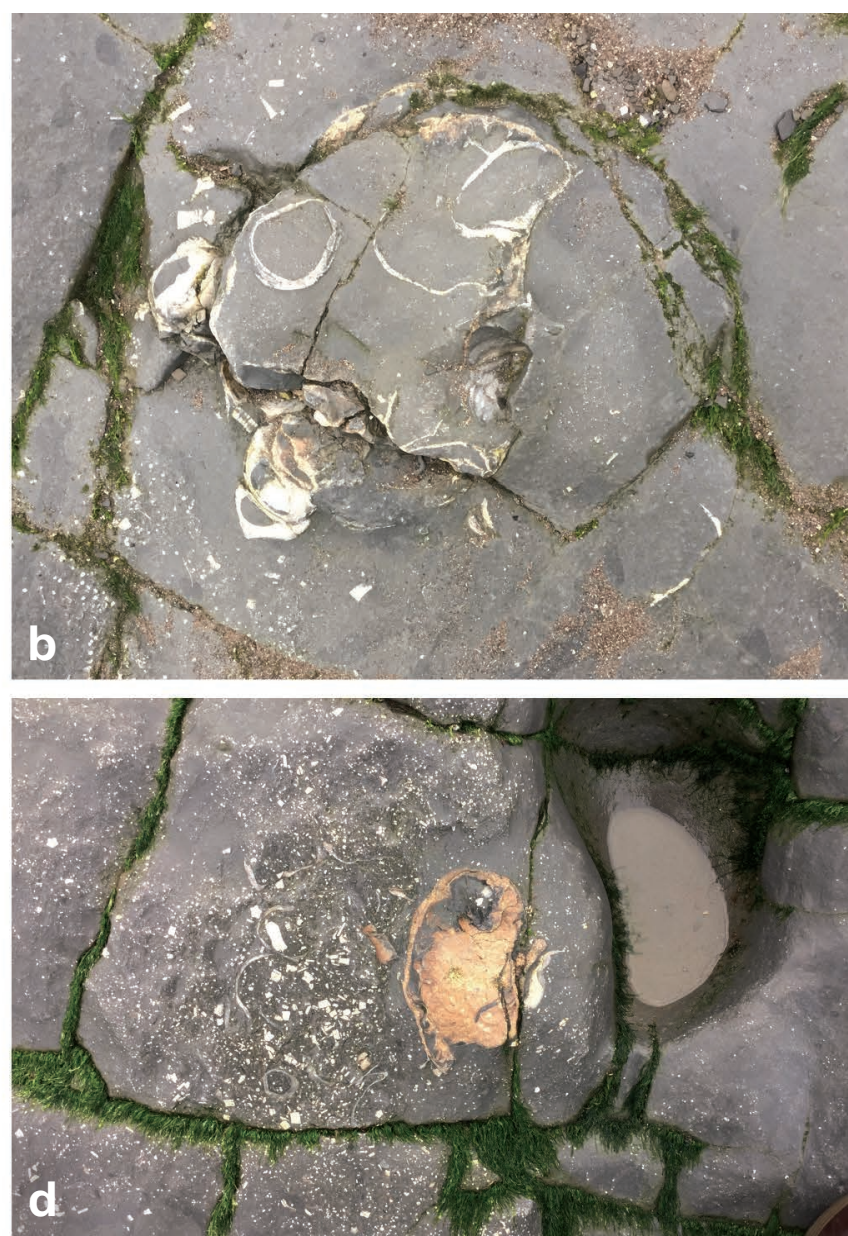

Text-fig. 8. a. Shell belonging to one flank of the conch a horizontally bedded individual with sveral large oysters attached to its underside indicating that the shell was either originally vertical or was flipped from one surface to the other by turbulance. Approximately $300 \mathrm{~mm}$ across. b. Crushed individual showing oysters encrusting both flanks of the conch. $250 \mathrm{~mm}$ in diameter. c. Wave-worn conch showing oysters attached to the umbilicus, the venter and possibly the inside of the body-chamber. Tape measure for scale. d. Flank of conch with crinoid debris and oysters spread around its periphery. Scope of image approximately $350 \mathrm{~mm}$.

and are in continuum with crinoid debris outside the perimeter of the conch.

The few ammonoids that occur in the Main and Upper Cenoceras beds are represented by Arnioceras, Coroniceras and Paracoroniceras. These may reach $250 \mathrm{~mm}$ in diameter but are generally less than $70 \mathrm{~mm}$ and are both vertically and horizontally embedded. In general, the remaining shell consists of a thin and often diffuse layer, possibly composed of white aragonite. In those examples where the contents of the inner whorls are visible, none contain septa, and in at least one specimen (Text-fig. 9b), the inside of the conch is invested with disseminated crinoid debris and an oyster shell.

\section{Interpretation}

Although a few occur through the unit, the bulk of nautilids present in the Main Cenoceras Bed appear to lie close to the top of the unit, and might be presumed to represent a single population, particularly as there is no obvious sedimentological evidence visible in vertical sections of this unit that would suggest a break in sedimentation. The range of preservational styles observed amongst these conchs is so broad as to suggest that this horizon incorporates material that probably had several distinct taphonomic histories.

\section{Compression of conchs}

All the horizontally resting conchs, whether complete or body-chambers alone, are crushed to a greater or lesser degree. Those conchs that remain uncrushed or relatively undeformed are vertically embedded individuals, and consist equally of body-chambers and whole conchs. The reasons for this may be that conch was more resistant to compression when oriented vertically, and/or compressive stresses were more easily deflected around the conch than in the case of a horizontally embedded conch where the stress would be directly applied to the lateral flanks of the conch.

\section{Orientation}

The presence of vertical and subvertical conchs in the assemblage cannot be attributed to shallow water depths since several of the vertically embedded individuals consist only of body-chambers, implying breakage of the conchs. Moreover, Crick (1983) demonstrated that conch morphology was a major determinant of the depth to which an empty conch could maintain vertical poise. Since the conch morphology should be similar across this population, the majority of individuals would be expected to be either vertical or tilted with the conch largely intact, rather than horizontal. 

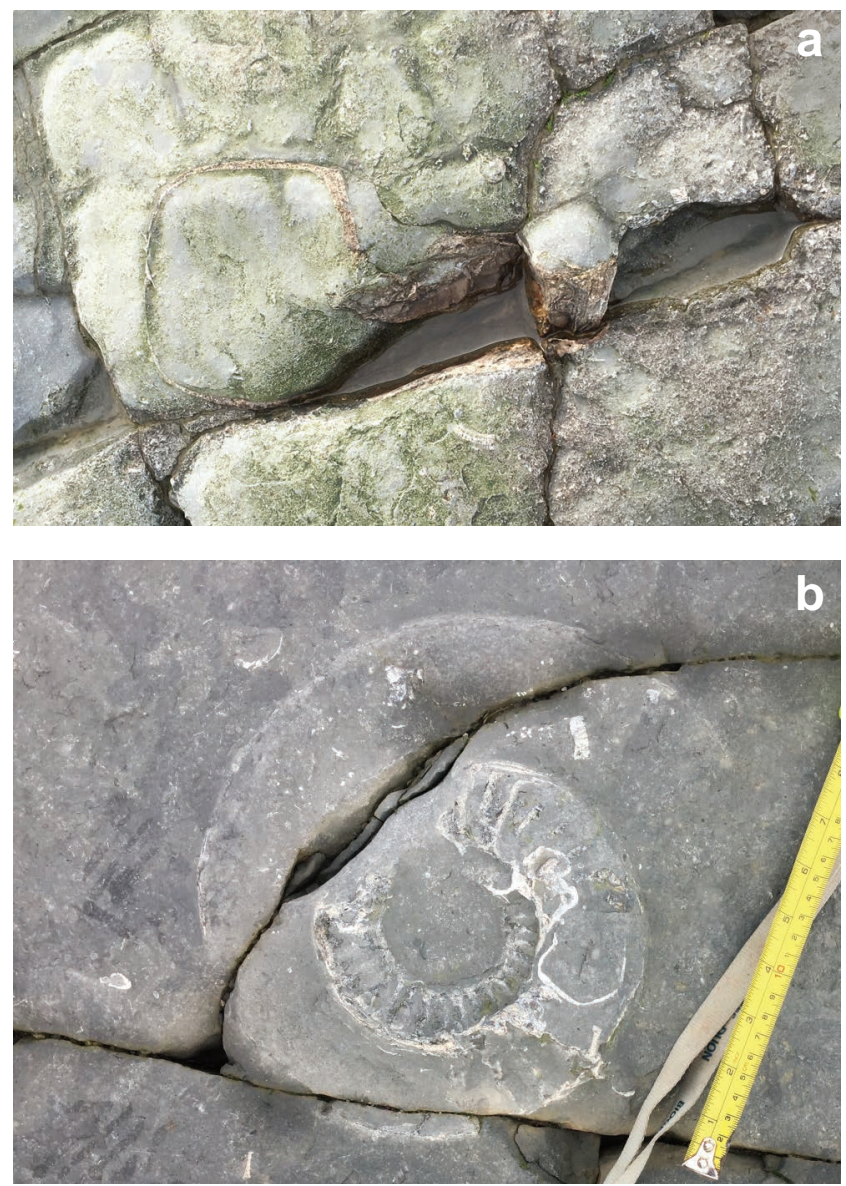

Text-fig. 9. a. Shorn-off, vertically embedded conch surrounded by layer of crinoid debris at level of planation of shell and with some debris within the conch at this level. Lateral width of body-chamber $80 \mathrm{~mm}$. b. Example of ammonite that occurs rarely in the Main Cenoceras Bed. Note the poorly defined shell particularly on the outer whorl, suggesting partial dissolution. Tape measure for scale.

\section{Sediment fill}

The distribution of sediment and sparite within the conchs indicates that several different pathways may be involved. Septa appear to be entirely missing in approximately a quarter of the phragmocones, and the inner whorls infilled with the same sediment as that of the surrounding matrix, implying that the septa may have been broken up and flushed out prior to the penetration of any sediment. In other individuals, sediment appears to have penetrated beyond the body-chamber into the outer whorls, probably through broken connecting rings. Penetration of sediment beyond the outer whorls appears to have been limited with camerae remaining largely devoid of sediment other than a coating of sparite. The attenuation of sediment fill in the inner whorls may be the consequence of sediment filling the outer whorls and effectively choking the passage of sediment to the inner whorls.

The presence of cemented masses of broken septa embedded in sediment in the inner whorls of some conchs (Text-fig. 6c) may suggest that there was a small quantity of unconsolidated sediment present in inner whorls which became mixed with broken septa during the burial, loading and failure of the conch. Alternatively, the sediment may have been able to penetrate the phragmocone via fractures in the conch walls caused by the loading, or through damage caused by organisms burrowing in the sediment.

The discrete spread of crinoid debris inside and outside of the conch, which appears to rest on consecutive septa within the phragmocone (Text-fig. 6b), is difficult to account for unless the conch had been partially exhumed and the exposed part removed prior to its reburial.

\section{Associated organisms}

The presence of oysters and more rarely, thin-shelled bivalves attached to the inside of body-chambers provide unequivocal evidence for the post-mortem attachment of some of these organisms. The significance of the presence of oysters on the underside of the preserved flank (Text-fig. $8 \mathrm{a}$ ) or on both flanks (Text-fig. 8b) is more ambiguous, and might be explained by:

1. In vivo attachment of oysters on both flanks followed by the settlement of the empty conch on one flank, burying the attached biota.

2. Post-mortem attachment on both flanks of a vertically embedded conch, that later capsized to horizontal.

3. Post-mortem attachment to one flank of a horizontally bedded conch that was then flipped over, and the previously buried flank colonised.

Thus it is not possible to demonstrate that there were no in vivo attachments of bivalves or crinoids to the nautilid conchs, although evidence for the third option (above) may be supported by (1) the observation that some conchs consist either of body-chambers or phragmocones, implying that they have been broken up by some agency; and (2) the possibility that some conchs were at least partially exhumed; again implying that substrate conditions were at times sufficiently energetic to scour and possibly flip conchs over. Further evidence, which may be indicative rather than conclusive is that there are proportionately more vertically embedded conchs that appear to lack sclerobionts (Tab. 2), and that there are proportionately more observations of the occurrence of sclerobionts on the flanks of horizontally bedded conchs than on vertical conchs.

Apart from the evidence of bioturbation, the intervening areas between nautilid conchs are almost entirely devoid of macrofossils. This may suggest that the substrate was unable to support any permanent community, either because it was frequently anoxic or anaerobic and/or was insufficiently competent to support any weight or the attachment of any kind of anchoring structure. The Cenoceras conchs may have been raised sufficiently high above the surrounding substrate to avoid periodic anoxia, and would have provided a solid substrate for the attachment of other organisms. The empty nautilid conchs may then have been colonised by oyster spat falls.

Crinoid debris appears to be equally associated with horizontally, inclined and vertical nautilid conchs with the degree of articulation limited to infrequent fragments of stem that consisting up to ten ossicles. Much of the debris is dispersed into the surrounding sediment, but the concentration of debris around the nautilids indicates that they were associated with the conchs and may have provided a firm substrate for attachment. 
Table 1. Distribution of selected preservational states occurring in individuals observed in the Main Cenoceras Bed. Percentages given in each column are derived from the total number of observations for the category (column) divided by the number of observations of conchs within that class (row) and category.

\begin{tabular}{|c|c|c|c|c|c|c|c|c|c|c|}
\hline & 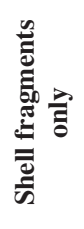 & 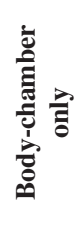 & 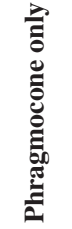 & 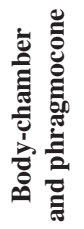 & 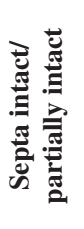 & 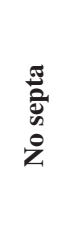 & 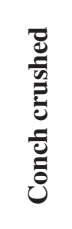 & 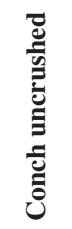 & 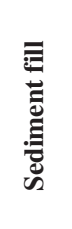 & 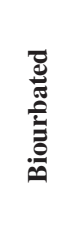 \\
\hline Horizontal (33) (53.3 \%) & 5 & 4 & 0 & 24 & 13 & 10 & 28 & 0 & 27 & 27 \\
\hline$\%$ & 71.4 & 28.6 & 0 & 64.9 & 59.1 & 62.5 & 65.0 & 0 & 52.9 & 52.0 \\
\hline Inclined (12) (20.0 \%) & 1 & 2 & 2 & 7 & 6 & 2 & 9 & 2 & 11 & 11 \\
\hline$\%$ & 14.3 & 14.3 & 66.7 & 18.9 & 27.3 & 12.5 & 21.0 & 22.2 & 21.6 & 22.0 \\
\hline Vertical (16) (20.7 \%) & 1 & 8 & 1 & 6 & 3 & 4 & 6 & 7 & 13 & 12 \\
\hline$\%$ & 14.3 & 57.4 & 33.3 & 16.2 & 13.6 & 25.0 & 14.0 & 77.8 & 25.5 & 24.0 \\
\hline $\mathrm{N}$ (cat.) & 7 & 14 & 3 & 37 & 22 & 16 & 43 & 9 & 51 & 50 \\
\hline $\mathbf{N}$ (meet.) & 7 & 14 & 3 & 37 & 22 & 16 & 43 & 9 & 51 & 50 \\
\hline
\end{tabular}

The dispersion of oyster shells into the surrounding sediment may have come about through the detachment of shells from the nautilid conchs, but could also indicate colonisation by later generations of spat fall, as there is some evidence of shells sequentially cemented to each other (Text-fig. 8b). The presence of disarticulated crinoid debris also indicates that the substrate (at least around the nautilid conchs) was normally oxygenated at intervals, as otherwise the lack of decay of tissues would left the crinoids preserved in an articulated condition. The association of Thallasinoides with the conchs also indicates oxygenated conditions, and may suggest that crustaceans could have been responsible for some of the damage to septa and their disappearance from some conchs (Fraaye and Jäger 1995).

The presence of a few horizontally bedded conchs that do not seem to be associated with sclerobionts, may indicate that these conchs were buried too rapidly, or intermittently buried such that sclerobionts were unable to successfully colonise the conchs.
The existence of several different modes of preservation within the Main Cenoceras Bed may indicate that that there were several different taphonomic pathways operating:

1. Individuals that remained at or close to the surface of the substrate and underwent damage including the separation of the body chamber and phragmocone and/or the destruction of septa, possibly through their disturbance and colonisation by crustaceans (see Fraaye and Jäger 1995).

2. Individuals that underwent partial burial or were exhumed, but the exposed portions of the whorls were subject to destruction through degradation of the shell fabric and attrition by currents and impacting objects. The exposed remains of the conch may have then been subjected to further colonisation.

3. The infilling of the outer whorls by mud while sparite precipitation took place within the inner whorls, followed by compression and crushing during the later stages of burial.

Table 2. Distribution of observations of oysters attached to the conchs or dispersed in the surrounding area. Percentages given in each column are derived from the total number of observations for the category (column) divided by the number of observations of conchs within that class (row) and category.

\begin{tabular}{|c|c|c|c|c|c|c|c|c|c|}
\hline & \multicolumn{9}{|c|}{ Oysters } \\
\hline & \multicolumn{5}{|c|}{ Attached } & \multicolumn{4}{|c|}{ Unattached } \\
\hline & 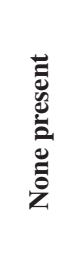 & 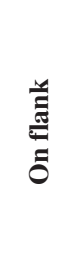 & 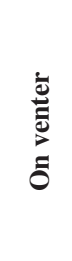 & 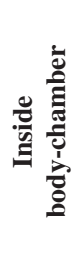 & 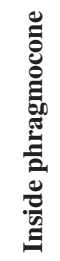 & 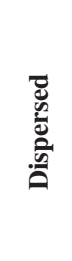 & 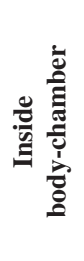 & 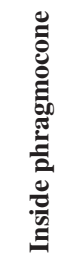 & 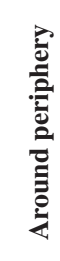 \\
\hline Horizontal (33) (53.3 \%) & 3 & 17 & 7 & 6 & 0 & 16 & 5 & 2 & 5 \\
\hline$\%$ & 25.0 & 65.4 & 41.2 & 42.9 & 0 & 59.3 & 55.6 & 40.0 & 71.4 \\
\hline Inclined (12) $(20.0 \%)$ & 2 & 5 & 3 & 6 & 1 & 7 & 2 & 1 & 2 \\
\hline$\%$ & 16.7 & 19.2 & 17.6 & 42.9 & 100 & 25.9 & 22.2 & 20.0 & 28.6 \\
\hline Vertical (16) $(26.7 \%)$ & 7 & 4 & 7 & 2 & 0 & 4 & 2 & 2 & 0 \\
\hline$\%$ & 58.3 & 15.4 & 41.2 & 14.2 & 0 & 14.8 & 22.2 & 40.0 & 0 \\
\hline
\end{tabular}


Processes (1 and 2) were prevalent on the substrate to just below the sea floor and could have provided recurrent sites for sclerobiont colonisation. If able to continue for a sufficient interval, these processes would also have led to the complete fragmentation of the conchs - for which there is some evidence from the presence of small conch fragments. Process (3) involved burial and the isolation of the conchs from destructive activities that took place on or just below the sea floor. Such isolation could have come about through the resumption or acceleration of sedimentation, or through extreme anoxia of the substrate, leading to the cessation of bioturbation and processes that might return conchs to the sea floor.

This suggests that the Main Cenoceras Bed may have formed from the steady accumulation of nautilid conchs over an extended interval, during which conchs underwent destruction on and just below the sea floor, but also acted as sites ('islands') for colonisation by filter feeders including oysters and crinoids. Diedrich (2010) reported on the association of ammonite accumulations with complexes of Thallasinoides burrows in the Cenomanian of north-west Germany and indicated that the burrows had been inhabited by drift-catching or suspension-feeding crustaceans. The association of Thallasinoides burrows with some of the Cenoceras conchs in the Main Cenoceras Bed may indicate that the conchs provided a degree of shelter and could also have provided a degree of relief, allowing the burrow entrances to be raised slightly above the surrounding substrate.

\section{Discussion}

Concentrations and accumulations of nautilid conchs have been reported from Mesozoic and Tertiary rocks where they have been variously attributed to an autochthonous population comprising conchs at all stages of development as well as being associated with jaws (Schlögl et al. 2011); allochthonous populations of nectonic conchs drifted into littoral and sublittoral habitats (Lukeneder and Harzhauser 2002); allochthonous populations accumulated as storm deposits (Cichowolski et al. 2012); or generally as timeaveraged accumulations in a mid-shelf situation (Luci and Cichowolski 2014). Characteristic of all these examples are the large sizes of populations involved as well as their relatively concentrated occurrences.

The nautilid accumulation described here from Helwell Bay appears to be more dispersed and consists of fewer individuals than those of the assemblages noted above. This accumulation is here interpreted as likely to represent the time-averaged accumulation of drifted individuals during an interval of reduced sediment accumulation. Many of the nautilid conchs provided colonisation sites for filter feeders under substrate conditions that were frequently unsuitable for colonisation in the intervening areas.

Given that ammonoids constitute the dominant nektobenthic component of the Hettangian and early Sinemurian macrofaunas of Britain, the occurrence of horizons containing relatively large numbers of nautilids and with very few ammonoids may be regarded as unusual. The occurrence at Helwell Bay is by no means unique, but the large area of the exposure and combined with the numbers of nautilids available for study render this location the most suitable for the investigation of this phenomenon.

It remains unclear as to why this assemblage should be dominated by nautilids rather than ammonites. Ammonites are quite rare in the Main and Upper Cenoceras Beds and are generally preserved as thin, diffuse and chalky shells, with the septa apparently missing. Their relative rarity may be explained by the early dissolution of the conchs, a phenomenon that as has been observed more generally in Blue Lias Formation sediments (Weedon et al. 2018). However, if this is the case here, it is unclear as to why

Table 3. Distribution of observations of thin-shelled bivalves attached to the conchs or dispersed in the surrounding area. Percentages given in each column are derived from the total number of observations for the category (column) divided by the number of observations of conchs within that class (row) and category.

\begin{tabular}{|c|c|c|c|c|c|c|c|c|}
\hline & \multicolumn{8}{|c|}{ Thin-shelled bivalves } \\
\hline & \multicolumn{4}{|c|}{ Attached } & \multicolumn{4}{|c|}{ Unattached } \\
\hline & 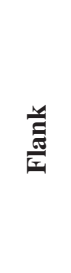 & 离 & 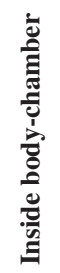 & 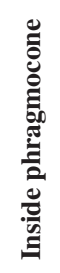 & 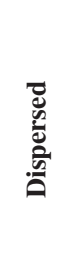 & 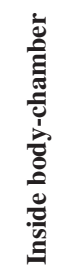 & 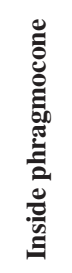 & \\
\hline Horizontal (33) (53.3\%) & 2 & 0 & 0 & 0 & 14 & 3 & 2 & 6 \\
\hline$\%$ & 40.0 & 0 & 0 & 0 & 46.6 & 60.0 & 66.7 & 66.7 \\
\hline Inclined (12) (20.0 \%) & 2 & 0 & 2 & 1 & 8 & 2 & 1 & 2 \\
\hline$\%$ & 40.0 & 0 & 100 & 100 & 26.7 & 40.0 & 33.3 & 22.2 \\
\hline Vertical (16) $(26.7 \%)$ & 1 & 1 & 0 & 0 & 8 & 1 & 0 & 1 \\
\hline$\%$ & 20.0 & 100 & 0 & 0 & 26.7 & 20.0 & 0 & 11.1 \\
\hline $\mathbf{N}$ (cat.) & 5 & 1 & 2 & 1 & 42 & 6 & 3 & 12 \\
\hline $\mathbf{N}$ (meet.) & 5 & 1 & 2 & 1 & 30 & 6 & 3 & 9 \\
\hline
\end{tabular}


Table 4. Distribution of observations of crinoid debris associated with the conchs and dispersed into the surrounding area. Percentages given in each column are derived from the total number of observations for the category (column) divided by the number of observations of conchs within that class (row) and category.

\begin{tabular}{|c|c|c|c|c|c|c|c|c|}
\hline & \multicolumn{8}{|c|}{ Crinoids } \\
\hline & 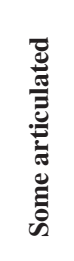 & 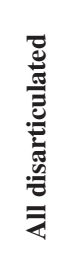 & 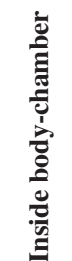 & 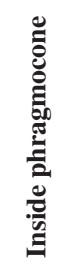 & 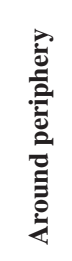 & 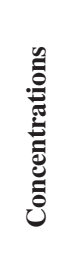 & 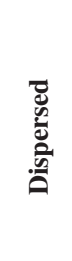 & 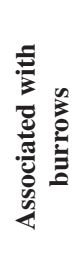 \\
\hline Horizontal (33) (53.3\%) & 9 & 22 & 9 & 3 & 8 & 12 & 22 & 13 \\
\hline$\%$ & 64.3 & 53.7 & 50.0 & 60.0 & 47.1 & 66.7 & 50.0 & 54.2 \\
\hline Inclined (12) (20.0 \%) & 2 & 10 & 5 & 1 & 4 & 2 & 12 & 5 \\
\hline$\%$ & 14.3 & 24.4 & 27.8 & 20.0 & 23.5 & 11.1 & 27.3 & 20.8 \\
\hline Vertical (16) (26.7 \%) & 3 & 9 & 4 & 1 & 5 & 4 & 10 & 6 \\
\hline$\%$ & 21.4 & 22.9 & 22.2 & 20.0 & 29.4 & 22.2 & 22.7 & 25.0 \\
\hline
\end{tabular}

the nautilid conchs did not suffer the same fate, given that the mineral component of the shell is aragonite in both ammonoids and nautilids.

The preservation of nautilids in the Main and Upper Cenoceras beds indicates that there were reductions or breaks in sedimentation, possibly combined with minor erosion of the substrate at this level. Interestingly, although Weedon et al. (2018) considered that there were no breaks in sedimentation in the late Bucklandi to basal Semicostatum zones on the West Somerset coast, they noted evidence suggesting reduced accumulation rates at the levels of beds 242-247 (of Whittaker and Green 1983), a few metres above the horizons discussed here.

\section{Conclusions}

Accumulations of conchs belonging to the nautilid Cenoceras occurring in the upper part of the Blue Lias Formation of the West Somerset Coast appear to have originated as a result of decreases in sedimentation rates rather than through the influx of a large living or moribund population. The modes of preservation of Cenoceras conches within the horizons investigated indicate that despite the homogenous appearance of the enclosing sediments, several breaks in sedimentation and possibly minor erosion events may be represented in these units. The association of suspension feeders including crinoid, oysters, other bivalves and crustaceans evidenced by Thalassinoides burrows with the nautilid conchs indicates that the latter functioned as 'island' sites for colonisation, but for reasons that may include anoxia and/or scouring, the intervening substrates show little evidence that they were ever colonised.

\section{Acknowledgements}

The authors express their thanks to Dr Ryoji Wani and another anonymous referee for valuable comments and suggestions for the improvement a previous version of the manuscript. We are also grateful to colleagues in Prague, including Jiří Kvaček, Štěpán Manda and Petr Štorch for their patience and assistance in the production of this paper.

\section{References}

Bloos, G., Page, K. N. (2002): Global Stratotype Section and Point for base of the Sinemurian Stage (Lower Jurassic). - Episodes, 25(1): 22-28.

Cichowolski, M., Pazos, P. J., Tunik, M. A., Aguirre-Urreta, M. B. (2012): An exceptional storm accumulation of nautilids in the Lower Cretaceous of the Neuquén Basin, Argentina. - Lethaia, 45: 121-138. https://doi.org/10.1111/j.1502-3931.2011.00271.x

Crick, R. E. (1983): The practicality of vertical cephalopod shells as palaeobathymetric markers. - Geological Society of America Bulletin, 94: 1109-1116.

https://doi.org/10.1130/0016-7606(1983)94<1109:TPO$\mathrm{VCS}>2.0 . \mathrm{CO} ; 2$

Diedrich, C. G. (2010): Huge accumulations of Upper Cretaceous giant ammonite shells in benthic islands of southern North Sea Basin of Central Europe. - Episodes, 33(3): 164-172.

Fraaye, R., Jäger, M. (1995): Decapods in ammonite shells: examples of inquilinism from the Jurassic of England and Germany. - Palaeontology, 38(1): 68-75.

Klug, C., Fuchs, D. (2010): An earliest Hettangian (Jurassic) belemnitid from Great Britain with a preserved proostracum. - In: Tanabe, K., Shigeta, Y., Sasaki, T., Hirano, H. (eds), Cephalopods - Present and Past. Tokai University Press, Tokyo, pp. 181-185.

Luci, L., Cichowolski, M. (2014): Encrustations in nautilids: a case study in the Cretaceous species Cymatoceras perstriatum, Neuquén Basin, Argentina. - Palaios, 29: 101-120.

https://doi.org/10.2110/palo.2013.062

Lukeneder, A., Harzhauser, M. (2002): Shell accumulations of the Nautilidae Aturia (Aturia) aturi (Bast) in the Lower Miocene Paratethys (lower Austria). - In: Summesberger, H., Histon, K., Daurer, A. (eds), Cephalopods 
- Present and Past. Abhandlungen der Geologischen Bundesanstalt, 57: 459-466.

Palmer, C. P. (1972): The Lower Lias (Lower Jurassic) between Watchet and Lilstock in north Somerset (UK).Newsletter on Stratigraphy, 2: 1-30. https://doi.org/10.1127/nos/2/1972/1

Schlögl, J., Chirat, R., Balter, V., Joachimski, M., Hudáčková, M., Quillévéré, F. (2011): Aturia from the Miocene Paratethys: An exceptional window on nautilid habitat and lifestyle. - Palaeogeography, Palaeoclimatology, Palaeoecology, 308: 330-338. https://doi.org/10.1016/j.palaeo.2011.05.037

Warrington, G., Cope, J. C. W. C., Ivimey-Cook, H. C. (1994): St Audrie's Bay, Somerset, England: a candidate Global Stratotype Section and Point for the base of the Jurassic System. - Geological Magazine, 131(2): 191-200.

https://doi.org/10.1017/S0016756800010724

Weedon, G. P., Jenkyns, H. C., Page, K. N. (2018): Combined sea-level and climate controls on limestone formation, hiatuses and ammonite preservation in the Blue Lias Formation, South Britain (uppermost Triassic - Lower Jurassic). - Geological Magazine, 155(5): 1117-1149. https://doi.org/10.1017/S001675681600128X

Whittaker, A., Green, G. W. (1983): Geology of the country around Weston-super-Mare. Memoir for 1:50 000 geological sheet 279, New Series, with parts of sheets 263 and 295. - Geological Survey of Great Britain, HMSO, London, $147 \mathrm{pp}$. 